IJBE: Integrated Journal of Business and Economics

e-ISSN: 2549-3280

DOI:10.33019/ijbe.v2i2.78

Date of Publication: 4 June 2018

Volume 2 Issue 2, pp. 194-200

\title{
Electronic Commerce: Theory and Practice
}

\author{
Margarita Išoraitè, Neringa Miniotienè \\ Vilniaus kolegija/The University Applied Sciences \\ misoraite@gmail.com
}

\begin{abstract}
Electronic commerce in the world is becoming an increasingly popular form of trade. Most shoppers start looking for products, descriptions and quality features online before buying a product. In order to provide customers with more convenience, more and more companies and existing stores are setting up their own online stores where a person can buy at a convenient time, even at night when regular stores are no longer working. Online stores allow you to save time spent by a person searching for a particular product and driving through shops. The article analyzes the concept of e-commerce, the advantages and disadvantages of electronic commerce, and the situation of electronic commerce in Lithuania.
\end{abstract}

Keywords: Electronic commerce, Internet, E-commerce advantages and disadvantages

\section{Introduction}

Electronic commerce is a business in which information technology is used to increase sales, business efficiency and provide a basis for new products and services. Through its activities, each company communicates with many other entities: it may be private or corporate clients, business partners, suppliers. When communicating with each other, these entities exchange various types of information: they inform themselves about their products and services, negotiate the terms of transactions, exchange documents, transmit and accept orders for goods, complain about inappropriate services, distribute press releases, etc. The flow of information is also carried out among all of these entities: managers and subordinates communicate with the company, marketing specialists talk about vendors and product managers. Internet popularity has provided many new opportunities for business. Accelerated and simplified communication and unimagined technical capabilities have enabled smart entrepreneurs to create advertisements, stores, and other promising items on their own, on the Internet. Moreover, the growing number of Internet users has increased the volume and profitability of the use of commerce and services.

\section{E-commerce Concept}

A stated Wikipedia, electronic commerce - the purchase and sale of goods or services on the internet. E-commerce is the pursuit of commercial activity through electronic tools. It is based on the electronic processing and transmission of information (text, video, audio). E-commerce involves many activities - e-commerce of goods and services, electronic delivery of digital 
information, electronic auctions, direct marketing to consumers. Electronic commerce can be widely applied in the following areas: e-trade; financial transactions in the provision of banking, financial leasing, insurance and other services, investments, speculative operations in currency and securities; other services markets: hotels, tourism, education, consulting, payment for utilities, advertising and other; between various business, public, public and other institutions, legal and natural persons, households and individuals (Misevičiūtè, 2001).

Table 1. Electronic Commerce Concept

\begin{tabular}{|c|c|}
\hline Author & Definition \\
\hline $\begin{array}{l}\text { Nanehkaran, Y. A. } \\
\text { (2013) }\end{array}$ & $\begin{array}{l}\text { Electronic commerce is a powerful concept and process that has } \\
\text { fundamentally changed the current of human life. Electronic commerce } \\
\text { is one of the main criteria of revolution of Information Technology and } \\
\text { communication in the field of economy. }\end{array}$ \\
\hline $\begin{array}{l}\text { Shahriari, S., } \\
\text { Shahriari, M., } \\
\text { Ggheiji, S. (2015) }\end{array}$ & $\begin{array}{l}\text { Electronic commerce, commonly known as E-commerce, is trading in } \\
\text { products or services using computer networks, such as the Internet. } \\
\text { Electronic commerce draws on technologies such as mobile commerce, } \\
\text { electronic funds transfer, supply chain management, Internet } \\
\text { marketing, online transaction processing, electronic data interchange } \\
\text { (EDI), inventory management systems, and automated data collection } \\
\text { systems. }\end{array}$ \\
\hline $\begin{array}{l}\text { Gangeshwer, D. K. } \\
\text { (2013) }\end{array}$ & $\begin{array}{l}\text { The effects of e-commerce already appear in all areas of business, from } \\
\text { customer service to new product design. It facilitates new types of } \\
\text { information based business processes for reaching and interacting with } \\
\text { customers like online advertising and marketing, online order taking } \\
\text { and online customer service, etc. }\end{array}$ \\
\hline Khan, A. G. (2016) & $\begin{array}{l}\text { Electronic commerce, or e-commerce, is the buying and selling of } \\
\text { goods and services on the Internet. Other than buying and selling, } \\
\text { many people use the Internet as a source of information to compare } \\
\text { prices or look at the latest products on offer before making a purchase } \\
\text { online or at a traditional store. }\end{array}$ \\
\hline Fichter, K. (2003) & $\begin{array}{l}\text { E-commerce is understood as part of the business, which also includes, } \\
\text { for example, video conferencing and teleworking. By definitions } \\
\text { available so far, the term "e-business" can be defined as follows: } \\
\text { business processes, commercial activities, or other economic tasks } \\
\text { FORUM Fichter, Environmental Consequences of E-Commerce } 27 \\
\text { conducted over the Internet or computer-mediated networks (Intranet, } \\
\text { etc.). }\end{array}$ \\
\hline Ritter, J. B. (1992) & $\begin{array}{l}\text { International electronic commerce is not simply defined by the absence } \\
\text { of paper documents. Indeed, though an important objective of many } \\
\text { commercial and administrative users is the elimination of paper, most } \\
\text { users will also admit that current implementation efforts remain } \\
\text { heavily inter-dependent upon the continued use of paper documents. }\end{array}$ \\
\hline $\begin{array}{l}\text { Ngai, E., W. T. and } \\
\text { Wat, F. K. T. (2002) }\end{array}$ & $\begin{array}{l}\text {, There is a growing interest in the use of electronic commerce (EC) as } \\
\text { a means to perform business transactions. For many businesses, it has } \\
\text { become a priority Through using EC; companies can connect with } \\
\text { their trading partners for "just in time production"' and "just in time }\end{array}$ \\
\hline
\end{tabular}




\begin{tabular}{|c|c|}
\hline Author & Definition \\
\hline & delivery", which improves their competitiveness globally. ,, \\
\hline Mansell, R, (2003) & $\begin{array}{l}\text { B2B electronic commerce is widely believed to have implications for } \\
\text { the complete value chain of business processes that firms become } \\
\text { involved in when they trade. B2B electronic commerce, enabled by the } \\
\text { Internet, is expected to increase the efficiency of internal firm } \\
\text { processes and to streamline inter-firm linkages. Firms of all sizes are } \\
\text { expected to benefit from reduced information asymmetries and } \\
\text { strengthened business relationships as a result of their introduction of a } \\
\text { range of electronic commerce applications }\end{array}$ \\
\hline $\begin{array}{l}\text { Gunasekarana, A., } \\
\text { Marrib, H. B., } \\
\text { McGaugheyc, R. E., } \\
\text { Nebhwanib, M. D. } \\
\text { (2002) }\end{array}$ & $\begin{array}{l}\text { EC provides new channels for the global marketing of tangible goods } \\
\text { and presents opportunities to create new businesses providing } \\
\text { information and other knowledge-based intangible products. }\end{array}$ \\
\hline
\end{tabular}

E-business can be supported by all market participants (Misevičiūtė, 2001):

- Business (B) with business (B): (B2B);

- Business (B) with government agencies $(\mathrm{G})$ : (B2G);

- Private and other business enterprises (B) with the budget, state-owned capital companies (G): (B2G);

- Public Authorities and Budget Firms (G) with Public Institutions and Budget Firms: (G2G);

- Business (B), public authorities and budget firms (G) with individual consumers and households (C), as well as by identifying buyers and recipients of electronic models: (B2C and $\mathrm{G} 2 \mathrm{C}$ );

- Individual consumers and households with each other: (C2C).

\section{E-commerce Advantages and Disadvantages}

Electronic commerce is a tool for promoting new forms and dimensions of business. After all, you can sell your online store seven days a week, 24 hours a day, and you do not need any special premises, sellers, complicated accounting systems or stores in each country. Your online store is accessible, visible and visited everywhere and always, and your customer does not even need to leave home to buy a product that he likes, he only has to click on the "buy" button and the courier will deliver his desired item directly to his home (see-marketing.lt, accessed 2017).

E-commerce offers the user the opportunity at any time, regardless of where it is located (as long as the user has access to the Internet) information on goods and services, as well as purchasing them. This removes the barriers associated with time and space constraints when acquiring goods or services. The user has the electronic space the ability to compare offers from different traders regarding price, quality aspect, and assessment seller's credibility. The user can personalize his purchase and keep himself from subjective criteria for determining the product's choice, such as seller's persuasion, alleged discounts shares. 
IJBE: Integrated Journal of Business and Economics

e-ISSN: 2549-3280

Table 2. E-commerce Advantages and Disadvantages

(Based on alinosbloggas.blogspot.co.id, webo.lt, and mususavaite.lt)

\begin{tabular}{|c|c|}
\hline Advantages & Disadvantages \\
\hline $\begin{array}{l}\text { Convenience - You save time by physically } \\
\text { shopping. You can shop anywhere you } \\
\text { have an Internet connection and at any } \\
\text { time. }\end{array}$ & $\begin{array}{l}\text { The ability to be cheated - Your money } \\
\text { security depends on your vigilance. So } \\
\text { before submitting your personal } \\
\text { information, check that the online store is } \\
\text { trusted. When you buy online, you risk not } \\
\text { getting or getting the same as the one shown } \\
\text { in the photo. }\end{array}$ \\
\hline $\begin{array}{l}\text { Information details and recommendations - } \\
\text { Detailed information is provided for each } \\
\text { item in the e-shop. Here you can find } \\
\text { product reviews and recommendations. }\end{array}$ & $\begin{array}{l}\text { It is easy to make a mistake on the price - } \\
\text { Keep in mind that the product will have to } \\
\text { pay more than specified. }\end{array}$ \\
\hline $\begin{array}{l}\text { Lower prices and better choices - Online } \\
\text { sellers do not have to pay rent or wages to } \\
\text { employees. It is convenient for you to } \\
\text { compare prices for the same product in } \\
\text { different e-shops in a short period. }\end{array}$ & $\begin{array}{l}\text { Lack of privacy - Some online stores even } \\
\text { unsolicited send you emails about various } \\
\text { stocks and new items. On the one hand, this } \\
\text { may seem useful, but on the other hand, it is } \\
\text { a way to get you more money. }\end{array}$ \\
\hline $\begin{array}{l}\text { Starting an e-business requires less } \\
\text { investment than traditional commerce }\end{array}$ & \multirow{2}{*}{$\begin{array}{l}\text { When ordering a product online, it often } \\
\text { takes a long time before it is delivered, and } \\
\text { shipping charges sometimes exceed the } \\
\text { price of the item, especially if the product is } \\
\text { ordered from abroad. Repaying your online } \\
\text { purchase may be more difficult than buying } \\
\text { a traditional store }\end{array}$} \\
\hline $\begin{array}{l}\text { A wider circle of consumers is attracted } \\
\text { (disabled, foreign clients) }\end{array}$ & \\
\hline $\begin{array}{l}\text { More varied and more convenient supply } \\
\text { of goods and services }\end{array}$ & \multirow{2}{*}{$\begin{array}{l}\text { Often money will not be refunded for } \\
\text { shipping, and in some cases, it will even } \\
\text { have to cover the cost of returning the } \\
\text { product itself. Also, when shopping online, } \\
\text { it is important to make sure the website is } \\
\text { trusted, and your credit card or online } \\
\text { banking data will be protected. Finally, } \\
\text { shopping online will not be able to see the } \\
\text { goods (like clothes). }\end{array}$} \\
\hline $\begin{array}{l}\text { Comfortable billing (bank charges, bank } \\
\text { link integration). }\end{array}$ & \\
\hline
\end{tabular}

The main advantage of e-commerce is to provide its current and potential customer with all information about the product, to offer to order and pay for it online, at any time of the day and anywhere, on the Internet, advice on matters of concern (Misevičiūtè, 2001).

Electronic commerce also has some failures. Studies have shown that $35 \%$ of expensive goods sold in virtual stores are pirated. Investigations have also shown buyers a lot of confidence (Misevičiūtè, 2001). 


\section{Statistical Data on E-commerce in Lithuania}

In the EU Member States, e-commerce in 2016 accounted for $9.4 \%$ of all retail sales. Compared to previous years, e-commerce grew by about $11 \%$, while trading areas shrank by about $1.5 \%$. Still more significant changes are recorded in those countries where e-commerce is already a relatively significant part of all retail sales. One such country is the United Kingdom. In this country's retail market, the share of online shopping is about $17 \%$ and is proliferating. At that time, the area of trade fell by more than $4 \%$ over the past year (Sagatauskas, A., 2018)

In Lithuania, the share of online shopping is still a relatively small part of all retail trade - in 2016 it was about $3.5 \%$. A Eurobarometer survey shows that every third person in the country has been online at least once in the EU. Thus, at present, a larger proportion of Lithuanians still enjoy visiting physical stores, and the volume of online sales is too small to have a real impact on the decline of traditional retail outlets. Vilnius is worth mentioning individually, with a trade area (679 sq. M) per capita now considerably lower than in Riga or Tallinn (998 sq. M and 817 sq. $M$ respectively). Therefore, in the future, we should still hear about the projects of new shopping centres in the capital of Lithuania.

According to the data of the EU statistical agency Eurostat, the indicators related to e-commerce have rapidly risen in Lithuania:

- In Lithuania, online sales of companies (excluding financial firms) grew from $18 \%$ in 2015 up to $22 \%$ in 2017.

- There is also a noticeable increase in the number of online purchases by businesses (in 2014, Internet purchases made up $25 \%$ and in 2017 it was already $28 \%$ ).

- The largest growth in corporate turnover from e-commerce - in 2017 rose almost double compared with 2014. (In 2014, the turnover of e-commerce companies was 7\%, and in 2017 it was already $13 \%$ ).

- When analyzing the statistics important for the development of e-commerce in Lithuania, it is important to mention that (based on The Lithuanian Department of Statistics at osp.stat.gov.lt):

○ Between 2015 and 2017, the percentage of households with a personal computer increased. 2015 it was $67.6 \%$, while in 2017 it grew to $73 \%$.

- Major cities in 2017 it has grown to $82.4 \%$.

- Internet access has also increased. 2015 it reached 68.3\%, and in 2017 it has grown to $75 \%$. Statistics show an increasing interest in the Internet.

- Analyzing the proportion of companies that have sold goods or services (received orders) by e-communications, it is noted that (based on The Lithuanian Department of Statistics at osp.stat.gov.lt):

○ Wholesale and retail networks in Lithuania grew from 25.2 percent in 2014 to $32.4 \%$ - 2016

- Computer programming, consultancy, and related activities; data processing, web server services (hosting) and related activities; Internet gateway service activities also increased from $23.9 \%$ in 2014 to $40.8 \% 2016$

○ Sales and retail sales increased from $23.2 \%$. In 2012, to 33.8 percent. -2016. 


\section{Conclusion}

Electronic commerce is usually defined as the automation of routine business procedures and operations and the transfer to virtual space. This process greatly increases business efficiency and simplifies everyday routine work. Up to now, it has been assumed that most e-commerce transactions are conducted across the globe, but recent research has shown that businesses are moving fast between local companies. Many businesses keep internet and e-commerce in a more convenient way to market their products on the local market (news.lt, accessed 2018). Most online retailers are cheaper than the same products offered in regular stores. This is the main reason why today's online stores are gaining market share. Some online stores have exceptional conditions where you do not have to pay for delivery at home for a certain amount. When trading online, less time is spent on paperwork, as in the e-commerce sales, as reports are automated. It is convenient for small businesses to go online because they can easily compete with bigger ones. Also, online sales are cost-saving - there is no need to rent an outlet to the store, and warehousing is not always necessary. It is much easier to access foreign markets on the Internet. The biggest shortage of online stores is that it is not possible to see a product before buying it (tv3.1t, accessed 2018).

\section{References}

1) Apsipirkimo Vieta - Elektroninè Parduotuvè. (n.d.). Retrieved 2018, from http://alinosbloggas. blogspot.lt/2010/09/pirkimo-internetu-privalumai.html13.

2) Elektroninė komercija. (2018, February 20). Retrieved 2018, from https://lt. wikipedia.org /wiki/Elektroninė_komercija

3) Elektronine komercija ir globalizacija. (n.d.). Retrieved 2018, from http://www.news.lt/ITnaujienos/Elektronine-komercija-ir-globalizacija.im?id=95369\&f=c

4) Elektroninès parduotuvès: Pliusai ir minusai. (n.d.). Retrieved 2018, from http://www. mususavaite.lt/elektronines-parduotuves-pliusai-ir-minusai/

5) Elektroninės parduotuvės privalumai. (n.d.). Retrieved 2018, from http://www.webo.lt/elektroninesparduotuves-privalumai.htm

6) Fichter, K. (2003). E-Commerce Sorting Out the Environmental Consequences. Journal of Industrial Ecology, (6)2.

7) Gangeshwer, D. K. (2013). E-Commerce or Internet Marketing: A Business Review from Indian Context. International Journal of $u$ - and e-Service, Science, and Technology, (6)6, pp.187-194.

8) Gunasekarana, A., Marrib, H., B., McGaugheyc, R., E., Nebhwanib, M., D. (2002). E-commerce and its impact on operations management. Int. J. Production Economics, (75), pp. 185-197.

9) Households have personal computers, Internet access. (2017). Retrieved 2018, from https://osp.stat.gov.lt/statistiniu-rodikliu-analize?indicator=S4R029\#/

10) Kas Yra E-Komercija. (n.d.). Retrieved 2018, from http://www.seo-marketing.lt/kas-yramarketingas/kas-yra-e-komercija.html

11) Khan, A., G. (2016). Electronic Commerce: A Study on Benefits and Challenges in an Emerging Economy. Global Journal of Management and Business Research: B Economics and Commerce, (16)1.

12) Internetinè prekyba: Nauda ir pavojus. (2010, May 03). Retrieved 2018, from https://www.tv3.lt/naujiena/387629/internetine-prekyba-nauda-ir-pavojus

13) Mansell, R. (2003). Electronic commerce: conceptual pitfalls and practical realities. Prometheus, (21)4, pp. 429-447.

14) Misevičiūtè, B. (2001). Elektroniné komercija [PPT]. Retrieved 2018, from http://kopustas.elen.ktu.lt /studentai/lib/exe/fetch.php?media=elektronine_komercija.ppt . 
15) Nanehkaran, Y., A. (2013). An Introduction To Electronic Commerce. International journal of scientific \& technology research, (2)4, pp. 190-193.

16) Ngai, E., W., T. Wat, F., K., T. (2002). A literature review and classification of electronic commerce research. Information \& Management, (39), pp. 415-429.

17) Ritter, J., B. (1992). Defining International Electronic Commerce. Northwestern Journal of International Law \& Business, (13)1, pp. 3-30.

18) Sagatauskas, A. (2018, January 01). Kada e. prekyba Lietuvoje rim. Retrieved from https://www.vz.lt/prekyba/2017/07/31/kada-e-prekyba-lietuvoje-rimciau-susigrums-su-tradicinemisparduotuvemis

19) Shahriari, S., Shahriari, M., Ggheiji, S. (2015). E-commerce and it impacts on global trend and market. International journal of research-Granthaalayah. (3)4, pp. 49-55.

20) The proportion of enterprises which sold (received orders for) goods or services via electronic networks. (2017). Retrieved 2018, from https://osp.stat.gov.lt/statistiniu-rodikliu-analize? indicator= S4R027\#/17 